Original Article

\title{
Blue and red light photoemitters as approach to inhibit Staphylococcus aureus and Pseudomonas aeruginosa growth
}

\author{
Fotoemissores de luz azul e vermelha como abordagem para inibir o crescimento de \\ Staphylococcus aureus e Pseudomonas aeruginosa
}

\author{
I. D. C. Galo ${ }^{a *}$ (D) R. P. Prado ${ }^{b}$ (iD) and W. G. Dos Santos ${ }^{a}$ (D) \\ aUniversidade Federal de Jataí - UFJ, Laboratório de Genética e Biologia Molecular, Programa de Pós-graduação em Ciências Aplicadas à Saúde, \\ Jataí, GO, Brasil \\ bUniversidade Federal de Catalão - UFCAT, Departamento de Medicina, Catalão, GO, Brasil
}

\begin{abstract}
The ability of pathogenic bacteria acquire resistance to the existing antibiotics has long been considered a dangerous health risk threat. Currently, the use of visible light has been considered a new approach to treat bacterial infections as an alternative to antibiotics. Herein, we investigated the antimicrobial effect of two range of visible light, blue and red, on Staphylococcus aureus and Pseudomonas aeruginosa, two pathogenic bacterial commonly found in healthcare settings-acquired infections and responsible for high rate of morbidity and mortality. Bacterial cultures were exposed to blue or red light $(470 \mathrm{~nm}$ and $660 \mathrm{~nm}$ ) provided by light-emitting diodes - LED. The fluencies and irradiance used for blue and red light were $284.90 \mathrm{~J} / \mathrm{cm}^{2}, 13.19 \mathrm{~mW} / \mathrm{cm}^{2}$ and $603.44 \mathrm{~J} / \mathrm{cm}^{2}, 27.93 \mathrm{~mW} / \mathrm{cm}^{2}$ respectively. Different experimental approaches were used to determine the optimal conditions of light application. Only exposure to blue light for 6 hours was able to inhibit about $75 \%$ in vitro growth of both bacterial species after 24 hours. The surviving exposed bacteria formed colonies significantly smaller than controls, however, these bacteria were able to resume growth after 48 hours. Blue light was able to inhibit bacterial growth upon inoculation in both saline solution and BHI culture medium. We can conclude that blue light, but not red light, is capable of temporarily retarding the growth of gram negative and gram positive bacteria.
\end{abstract}

Keywords: antimicrobial blue light, photoinactivation, photobiomodulation.

\begin{abstract}
Resumo
A capacidade das bactérias patogênicas adquirirem resistência aos antibióticos existentes há muito tempo é considerada uma ameaça perigosa à saúde. Atualmente, o uso da luz visível tem sido considerado uma nova abordagem no tratamento de infecções bacterianas como alternativa aos antibióticos. Neste trabalho, investigamos o efeito antimicrobiano de duas faixas de luz visível, azul e vermelha, em Staphylococcus aureus e Pseudomonas aeruginosa, duas bactérias patogênicas comumente encontradas em infecções adquiridas em instituições de saúde e responsáveis por alta taxa de morbimortalidade. As culturas bacterianas foram expostas à luz azul ou vermelha ( $470 \mathrm{~nm}$ e $660 \mathrm{~nm}$ ) fornecida por diodos emissores de luz - LED. As fluências e irradiâncias utilizadas para luz azul e vermelha foram $284,90 \mathrm{~J} / \mathrm{cm}^{2}, 13,19 \mathrm{~mW} / \mathrm{cm}^{2}$ e $603,44 \mathrm{~J} / \mathrm{cm}^{2}, 27,93 \mathrm{~mW} / \mathrm{cm}^{2}$, respectivamente. Várias abordagens experimentais foram utilizadas para determinar as condições ótimas de aplicação da luz. Apenas a exposição à luz azul por 6 horas foi capaz de inibir cerca de $75 \%$ o crescimento in vitro de ambas as espécies bacterianas após 24 horas. As bactérias expostas sobreviventes formaram colônias com um tamanho significativamente menor do que os controles, contudo, essas bactérias conseguiram retomar o crescimento normal após 48 horas. A luz azul foi capaz de inibir o crescimento das bactérias após sua inoculação em solução salina ou no meio de cultura rico em nutrientes BHI. Podemos concluir que a luz azul mas não a luz vermelha é capaz de retardar temporariamente o crescimento de bactérias Gram-negativas e Gram-positivas.
\end{abstract}

Palavras-chave: luz azul antimicrobiana, fotoinativação, fotobiomodulação.

\section{Introduction}

Antibiotic resistance is among the most important public health threats of the 21st century (WHO, 2014). The inappropriate, excessive and careless use of antibiotics is the single most important factor associated to this resistance (Chambers and Deleo, 2009; Schwarz et al., 2017; Khan et al., 2017). Recently, the World Health Organization (WHO) has published a list of infectious agents that urgently need new antibiotics as an effort to stimulate more research into this field of study (WHO, 2017). Among the species mentioned, it was highlighted species

*e-mail: idcgalo@gmail.com

Received: December 3, 2019 - Accepted: July 29, 2020 
such as Staphylococcus aureus (S. aureus) and Pseudomonas aeruginosa (P. aeruginosa).

S. aureus (Gram-positive facultative anaerobe bacterium) and $P$. aeruginosa (Gram-negative facultative anaerobe bacterium) are important pathogens due to its abundance in various types of environment its and ability to cause both local superficial infections as more severe invasive infections (Chambers and Deleo, 2009; Falkinham III et al., 2015; Oliver et al., 2015; Chaney et al., 2017; Feng et al., 2017; Monaco et al., 2017; Freitas et al., 2018).

Both $S$. aureus as $P$. aeruginosa have extraordinary genetic plasticity to develop and acquire antibiotic resistance genes and when both coexist in one infection may lead to the death of a patient (Oliver et al., 2015; Chaney et al., 2017; Monaco et al., 2017; Alves et al., 2018). Thus, the potential risk of antibiotic bacterial resistance for the human health is a matter of great concern worldwide demonstrating the need for novel alternative approaches to deal with this problem (Bumah et al., 2013; Lupke et al., 2017).

In this context photobiomodulation has been recognized as a good non drug alternative antibiotic (Bumah et al., 2015; Sousa et al., 2015). Several authors including our laboratory team have shown that blue light $(405-470 \mathrm{~nm})$ is able to promote considerable bacterial growth inhibition in vitro demonstrating its potential for therapeutic use in superficial infected wounds what could avoid more severe invasive infections (Lucca et al., 2012; Dai et al., 2013; Sousa et al., 2015; Galo et al., 2020 - in press). Yet, the evaluation of other visible light wavelengths is still controversial in the literature, particularly in relation to the red light (Pereira et al., 2014; Gomes et al., 2018).

Light at 600-660 nm wavelength are commonly used as method in tissue regeneration, reduction of local inflammation and even as superficial analgesic therapy (Hadis et al., 2016; Özberk et al., 2018). However, the use of red light for bacterial infection is subject of exhausting debate since data in the literature are still controversial (Marciano et al., 2012; Kim et al., 2013; Barboza et al., 2015; Gomes et al., 2018).

Therefore, the aim of this study was to compare the potential photobiomodulation action of red light $(660 \mathrm{~nm})$ and blue light $(470 \mathrm{~nm})$ irradiation in in vitro cultures of S. aureus and P. aeruginosa.

\section{Material and Methods}

\subsection{Bacterial cultures and growth determination}

S. aureus (ATCC 25923) and P. aeruginosa (ATCC 27853) strains were kindly provided by Dr. Alexandre Braoios from Laboratory of Microbiology, Federal University of Goiás. Bacteria were grown on $55 \mathrm{~mm}$ glass or polystyrene Petri dishes plates containing sterile Mueller-Hinton agar $(\mathrm{MH})$ or nutrient agar. Alternatively, strains were grown in $4 \mathrm{ml}$ of sterile brain-heart infusion broth (BHI) media. Before each experiment, bacterium was inoculated in sterile saline solution, in order to obtain a scale of 0.5 McFarland turbidity standard $\left(1.5 \times 10^{8} \mathrm{CFU} / \mathrm{mL}\right)$ and then serial dilutions were made and streaked on solid medium to obtain isolated colonies. The final inoculum was performed using a Drigalski spatula to spread $100 \mu \mathrm{L}$ of bacterial solution per plate. All the procedures were performed under sterile conditions and bacterial cultures were incubated at a temperature of $36.5^{\circ} \mathrm{C}$ for $24-48$ hours.

The number of colonies grown on plates was determined by using the software ImageJ. The diameter of the colonies was determined on digital photos taken from the plate (180 dpi, 24 bits, $4608 \times 3456$ pixels) by using a Canon PowerShot SX400 IS digital camera. For colony counting it was used the plugin Colony Counter adjusted to the following parameters "Size" minimum 300 and maximum de 10000 pixel, “Circularity" minimum 0.85 and maximum 1.0. The diameter measurement of the colonies was performed to compare the size of the surviving colonies after exposure to the photoemission compared to the controls not exposed after 24 and 48 hours incubation. A set of marks were drawn on millimetric labelled paper placed on the bottom of the Petri dish, in order to allow the exact positioning of the colonies and to precisely calibrate the software.

\subsection{Light emitters}

Two light emitters, blue and red, with $3 \mathrm{~W}(700 \mathrm{~mA})$ power were built, each one containing three LightEmitting Diode (LED). The blue light emitter consisted of a continuous beam of $470 \mathrm{~nm}$ wavelength peak with a radiometric power of $850 \mathrm{~mW}$. The red light emitter consisted of a continuous beam of $660 \mathrm{~nm}$ wavelength peak with a radiometric power of $1800 \mathrm{~mW}$. The estimate Irradiance and fluency values are specified for each experimental protocol used. Considering the variables that can influence the final result in an experimental in vitro setting, optimal parameters were previously defined such as distance between the LED and bacterial cultures and time of exposure, a factor that can generate different fluencies for each emitter.

\subsection{Determination of the temperature variability on the irradiated agar surface}

The minimum distance between the emitter and the cultures that does not promote great temperature variability on the culture surface was previously determined. One approach consisted of exposing a thermometer to the light emitter positioned at a distance of $3 \mathrm{~mm}$ and $6 \mathrm{~mm}$ between the LEDs and the surface for two hours while a control remained positioned on the same surface but not exposed to light. In the second approach a tube containing $1 \mathrm{~mL}$ of saline solution was exposed to blue light for 6 hours with the LED emitter positioned at a distance of $1 \mathrm{~cm}$ from the liquid while a control tube was not exposed. The temperature was measured during the entire experiment.

\subsection{Effect of red and blue light on bacterium growing on solid agar plate}

In order to avoid premature drying of the agar on the Petri dish during the experiment, that could interfere with the growth of inoculated bacteria, an infrared filter (a transparent glass recipient with $3 \mathrm{~cm}$ of height filled with $800 \mathrm{ml}$ of water) was positioned between the light emitter and bacterial culture. The LEDs were positioned 
at a distance of $5.5 \mathrm{~cm}$ from the agar on the plate providing irradiances of $13.19 \mathrm{~mW} / \mathrm{cm}^{2}$ and $27.93 \mathrm{~mW} / \mathrm{cm}^{2}$ for the blue and red emitter respectively. Dishes previously inoculated with bacteria were exposed for 6 hours generating fluencies of $284.90 \mathrm{~J} / \mathrm{cm}^{2}$ and $603.44 \mathrm{~J} / \mathrm{cm}^{2}$ for the blue and red emitters respectively. After this exposure, the plates were incubated for 24 and 48 hours at $36.8^{\circ} \mathrm{C}$. The experiment was repeated 6 times for each bacteria strain. Each experiment consisted of 9 glass dishes containing $\mathrm{MH}$ where 3 dishes were irradiated with blue light, 3 dishes were irradiated with red light and 3 dishes were controls non irradiated. After incubation, the number and size of the colonies were determined as described before. To investigate if the material used in the manufacture of the Petri dish could influence the effect of the light the same protocol described above was used but with polystyrene dishes instead of glass dishes.

\subsection{Effect of red and blue light on bacterium inoculated on liquid medium}

For this experiment, bacterium inoculated on liquid medium was exposed to blue and red light before seeding onto solid agar dishes. Initially, the test was performed using a $1: 10000$ dilution in $0.9 \%$ saline from a $0.5 \mathrm{McF}$ arland turbidity, in order to mimic a poor nutrient medium condition. One $\mathrm{mL}$ of this dilution was distributed in glass tubes of $4 \mathrm{~mL}$ capacity, aligned to the respective LED being tested and exposed for 3 hours, corresponding to fluencies of $157.78 \mathrm{~J} / \mathrm{cm}^{2}$ for blue light and $334.36 \mathrm{~J} / \mathrm{cm}^{2}$ for red light. The distance between the LED and the liquid surface was adjusted to $2 \mathrm{~cm}$ allowing irradiances of $14.61 \mathrm{~mW} / \mathrm{cm}^{2}$ and $30.96 \mathrm{~mW} / \mathrm{cm}^{2}$ for the blue and red light respectively. Controls were similar to the experimental test tubes, but the inoculum was not exposed to the LEDs. For each test tube it was prepared 9 dishes containing $\mathrm{MH}$ agar and each one was then inoculated with $100 \mu \mathrm{L}$ of the $S$. aureus or $P$. aeruginosa solution and seeded by using a Drigalski spatula. The same procedure was followed to test bacteria previously inoculated in the $\mathrm{BHI}$ (nutrient rich) instead of saline solution.

\subsection{Statistical analysis}

Statistical analysis was performed using the software SPSS 17.0. The data were expressed as mean \pm standard deviation. The normality of the sample distribution was confirmed by the Shapiro-Wilk test. Student's t-test and Mann-Whitney U test ( $\mathrm{p}<0.05$ ) were used to compare experimental and control groups. When appropriate, percentage of growth inhibition was calculated by dividing the mean of the surviving colonies in experimental plate and its respective control.

\section{Results}

\subsection{Influence of the distance of LED light position on the} temperature of the irradiated surface

LEDS positioned at $3 \mathrm{~mm}$ from the surface of solid medium increased the temperature from $27^{\circ} \mathrm{C}$ to more than $40^{\circ} \mathrm{C}$ after 10 minutes of exposure. At $6 \mathrm{~mm}$ distance, the maximum temperature measured at the surface of the medium was $36.3{ }^{\circ} \mathrm{C}$ for the blue LED and e $36.5{ }^{\circ} \mathrm{C}$ for the red LED. Therefore, to be cautious and to avoid major temperature variation, the smallest distance used in the experiments was $1 \mathrm{~cm}$. At this distance the maximum temperature reached was $30.1{ }^{\circ} \mathrm{C}$ for the blue LED and $30.6{ }^{\circ} \mathrm{C}$ for the red LED after exposure for 30 minutes and these temperatures remained unchanged even after 120 minutes. The exposure of light on liquid medium showed only a discreet increase in the temperature, varying from $27{ }^{\circ} \mathrm{C}$ to $27.5^{\circ} \mathrm{C}$ for the blue light and to $27.8^{\circ} \mathrm{C}$ for the red light after 360 minutes of exposure.

\subsection{Effect of the photoemission on bacterial growth after seeding on agar plate}

Exposure of bacterial freshly seeded on agar plate to blue light for 6 hours and then incubated for 24 hours at $36.8{ }^{\circ} \mathrm{C}$ inhibited the bacterial growth for both species analyzed. The average number of $S$. aureus colonies formed after exposure to blue light was $27.33 \pm 6.65$. This was significantly smaller than untreated control (132.33 \pm 6.02 colonies, $\mathrm{p}=0.049$ ) corresponding to de $79.17 \pm 5.9 \%$ growth inhibition. In contrast, exposure to red light showed no significant differences in the number of colonies (126.66 \pm 1.53 colonies) compared to untreated controls ( $p=0.275$ ) (see Figure 1). Similar inhibition pattern was observed for $P$. aeruginosa where $82 \pm 8.54$ colonies grew after irradiation with blue light and a significantly smaller number grew on the untreated controls $(229 \pm 10.81$ colonies, $p=0.049)$. Dishes irradiated with red light, in contrast, showed an average of $241 \pm 9.53$ colonies indicating no inhibition (Figure 1).

The diameter of the colonies that survived the light treatment after $24 \mathrm{~h}$ was measured since it was observed that they were smaller than the colonies that grew in the untreated control plates. The average diameter of the $S$. aureus and $P$. aeruginosa colonies previously exposed to blue light was $0.31 \pm 0.07 \mathrm{~mm}$ and $0.46 \pm 0.05 \mathrm{~mm}$ respectively. These numbers are significantly smaller than the diameters of their respective controls $(0.56 \pm$ $0.09 \mathrm{~mm}$ e $0.74 \pm 0.02 \mathrm{~mm}, \mathrm{p}=0.049$ ). These differences

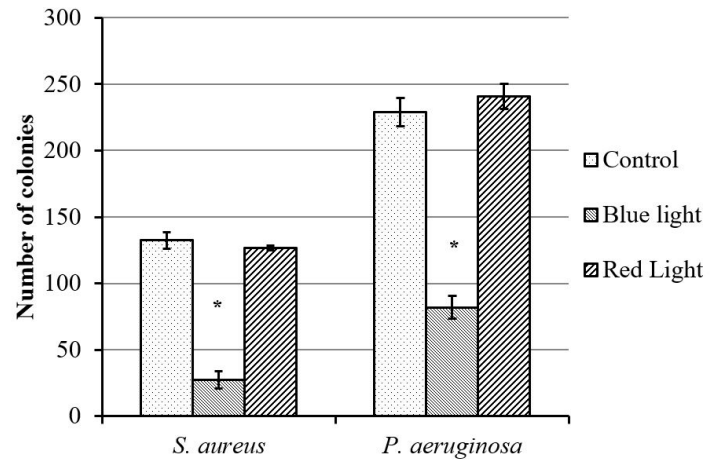

Figure 1. Effect of blue and red light -exposure on the growth of $S$. aureus e $P$. aeruginosa determined by the number of colonies formed after $24 \mathrm{~h}$ incubation. *Statistically significant difference using Mann-Whitney U test $(p<0.05)$ for independent samples. 
were not observed for both bacterial lineages exposed to red light, $0.51 \pm 0.1 \mathrm{~mm}$ for $S$. aureus and $0.75 \pm 0.03 \mathrm{~mm}$ for $P$. aeruginosa (Figure $2 \mathrm{~A}$ ). Interestingly, after and additional incubation for $24 \mathrm{~h}$ ( $48 \mathrm{~h}$ total), the average diameter of the colonies from both bacterial lineages, treated with blue or red light showed no difference in comparison to their respective controls. For S. aureus, controls showed colonies with $1.82 \pm 0.31 \mathrm{~mm}$ diameter; blue light exposed $1.79 \pm 0.24 \mathrm{~mm}$ and red light exposed $1.84 \pm 0.23 \mathrm{~mm}$. For $P$. aeruginosa, controls showed colonies with $2.05 \pm 0.02 \mathrm{~mm}$ diameter; blue light exposed $2.03 \pm 0.04 \mathrm{~mm}$ and red light exposed $2.04 \pm 0.07 \mathrm{~mm}$ (Figure 2B).

Since light have physical properties that can be influenced by different material while it passes through, we sought to investigate if plates made by plastic or glass could influence the inhibitory effect observed with the exposure of bacterial culture to blue light. The number $S$. aureus colonies grown on glass Petri dishes after 24 hours incubation was $137.33 \pm 6.02$ for the control, $31.66 \pm 5.68$ for bacteria exposed to blue light and $136.33 \pm 7.23$ for those exposed to red light. These values were not statistically significant from those calculated when polystyrene dishes were used, $137.66 \pm 8,08$ (controls), $33.8 \pm 10.69$ (blue light) and $144.33 \pm 5.85$ (red light). Similar results were found for $P$. aeruginosa. When glass dishes were used, controls showed $251.66 \pm 8.02$ colonies; blue light exposed group: $95 \pm 6.55$ and red light exposed group: $248.33 \pm 5.03$. When bacteria were seeded on polystyrene dishes, controls showed $247.74 \pm 7.5$ colonies; blue light exposed group: $91.8 \pm 6,5$ and red light exposed group: $250.66 \pm 8.5$
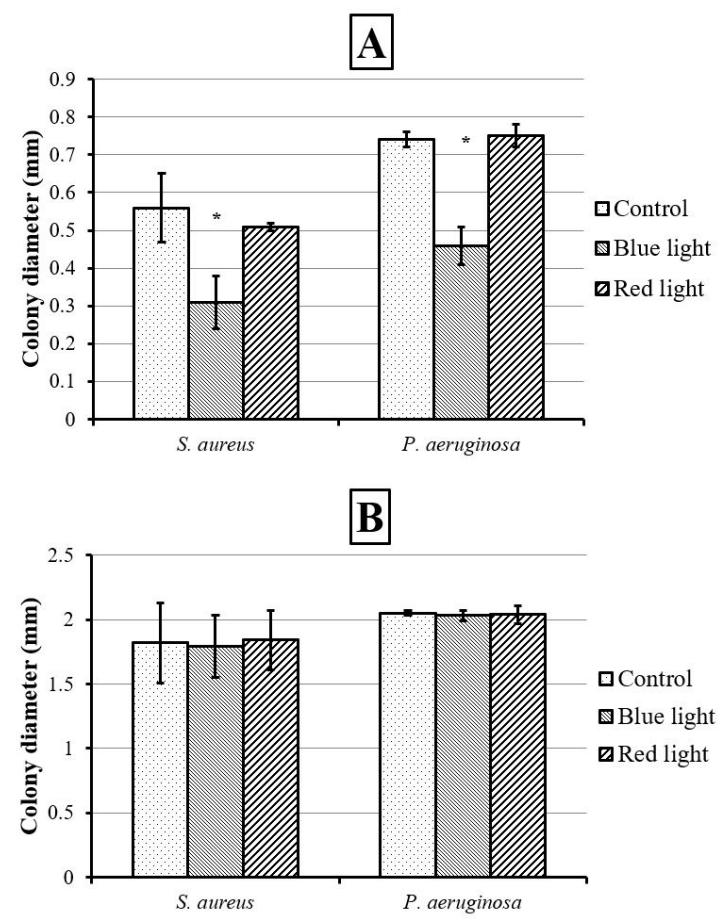

Figure 2. Diameter of $S$. aureus and $P$. aeruginosa surviving colonies after exposure to blue and red light for 6 hours and incubated for 24 hours (A) and 48 hours (B). *Statistically significant difference using Mann-Whitney $U$ test $(\mathrm{p}<0.05)$ for independent samples.
(Figure 3). These results are consistent however with the fact that blue light, but not red light can inhibit bacterial proliferation until 24 hours after exposure. S. aureus seeded on glass or polystyrene dishes and exposed to blue light showed $76.88 \pm 4.32 \%$ and $75.53 \pm 7.55 \%$ growth inhibition while $P$. aeruginosa showed $62.24 \pm 2.34 \%$ e $62.93 \pm 2.29 \%$ growth inhibition respectively (Figure 3).

\subsection{Effect of the photoemission on bacterial liquid solution} before seeding on solid agar plate

The exposure to blue or red light of bacteria in liquid medium before seeding on agar plate showed the same effect on growth as seen when the light was directly applied on bacteria inoculated on solid agar plate. When $S$ aureus or $P$. aeruginosa bacteria diluted on saline solution were exposed to blue light for 3 hours, a great inhibition on the growth could be observed ( $\mathrm{p}=0.049$ ). While $S$ aureus and $P$. aeruginosa control dishes showed $204 \pm 9.54$ and $338.7 \pm 13.5$ colonies 24 hours after incubation, their respective experimental groups exposed to blue light showed $4.66 \pm 2.08$ and $133.3 \pm 15.63$-colonies. On the other hand, bacteria exposed to red light under the same conditions showed no inhibition on growth, i.e., S aureus and P. aeruginosa dishes showed $208.66 \pm 3.51$ and $340.7 \pm 7.51$ -colonies after 24 hours incubation respectively (Figure 4).

We wanted to know if nutrient rich liquid medium could influence on the growth inhibition induced by

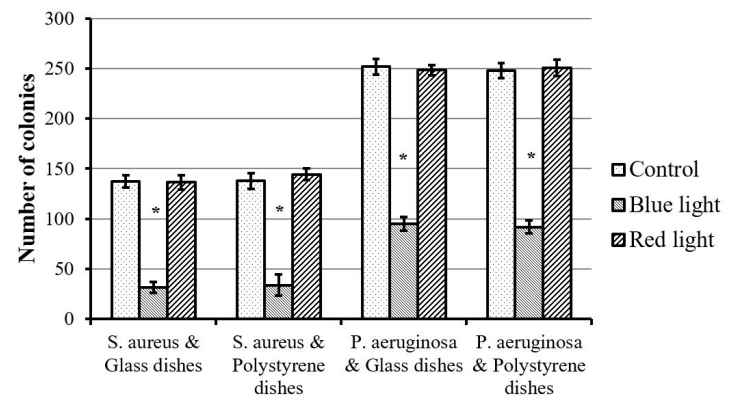

Figure 3. Determination of the influence of glass or polystyrene plate on the antimicrobial effect of red or blue light in S. aureus and $P$. aeruginosa cultures. *Statistically significant difference using Mann-Whitney U test $(\mathrm{p}<0.05)$ between blue light exposed group and control groups.

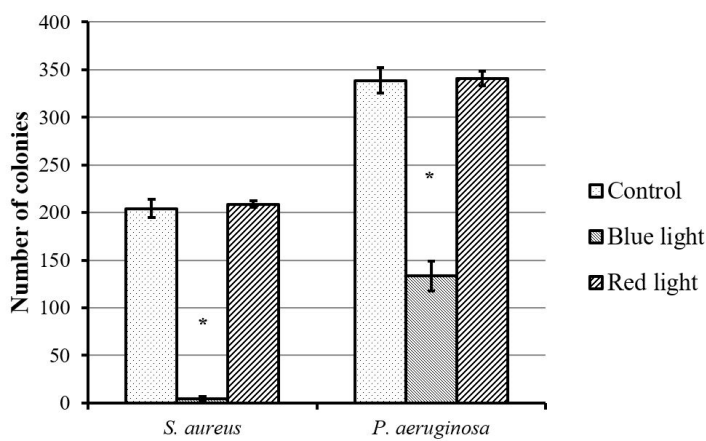

Figure 4. Effect of blue and red light on S. aureus e P. aeruginosa diluted in saline solution $(0.9 \% \mathrm{NaCl})$ applied for a period of 3 hours. *Statistically significant difference using Mann-Whitney U test $(p<0.05)$ between blue light exposed group and control groups. 
blue light. Therefore, we used the same experimental approach mentioned above but instead of saline solution we irradiated bacteria diluted in BHI broth. As expected, the number of colonies produced were higher in this medium, 1,120.33 \pm 94 and 1,957 \pm 54.5 colonies for $S$. aureus and $P$. aeruginosa respectively. The exposure to blue light once again was able to inhibit growth in both bacterial lineages, where $S$. aureus showed $551.33 \pm 52.5$ colonies and $P$. aeruginosa showed $796 \pm 12.53$ colonies after 24 hours incubation. The red light exposure, in contrast, did not show inhibition for both $S$. aureus $(1.146,33 \pm 57.39$ colonies) and $P$. aeruginosa (1,952 \pm 26.21 colonies; Figure 5).

Although in this experimental approach using BHI we could also observe a decrease in the number of colonies after exposure to blue light for 3 hours, the calculated percentage of inhibition was not statistically significant from the percentage of inhibition seen when saline solution was used, i.e., saline $(60.63 \pm 4.24 \%)$ and BHI $(59.29 \pm 1.54 \%)$ at least for $P$. aeruginosa $(\mathrm{p}=0.513)$. However, the inhibition induced by blue light on the growth of S. aureus diluted in saline solution (97.67 $\pm 1.13 \%$ ) was higher than the inhibition demonstrated for this bacterium when it was diluted on BHI medium (50.67 $\pm 4.61 \%$; $=0.049$ ) (Figure 6).

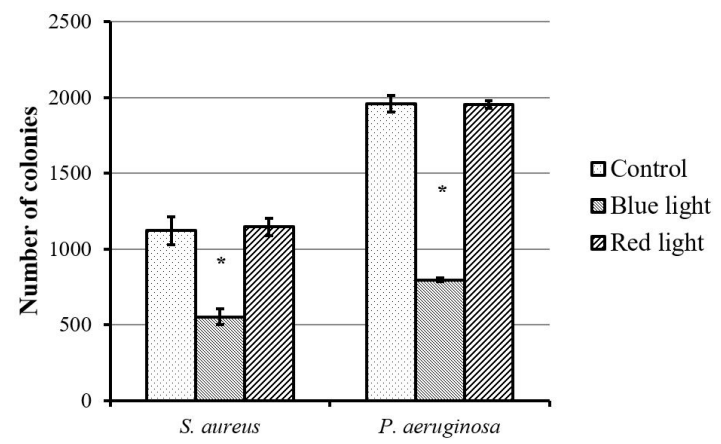

Figure 5. Effect of blue and red light on $S$. aureus e $P$. aeruginosa diluted in BHI nutrient rich medium applied for a period of 3 hours. *Statistically significant difference using Mann-Whitney U test $(p<0.05)$ between blue light exposed and control groups.

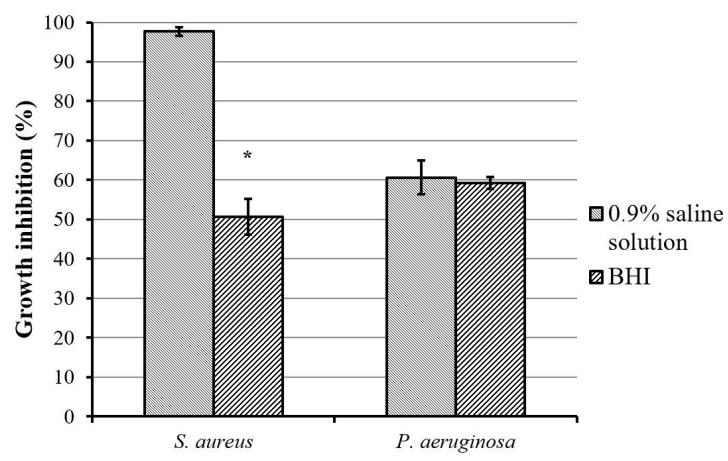

Figure 6. Percentage of growth inhibition induced by blue light on bacteria inoculated on saline solution or nutrient rich BHI broth. *Statistically significant difference using Mann-Whitney $\mathrm{U}$ test $(\mathrm{p}<0.05)$ between blue light exposed $S$. aureus in saline solution and BHI broth.

\section{Discussion}

In vitro studies suggest that light at wavelengths between $625-1000 \mathrm{~nm}$ (from red to infrared) when applied alone does not induce increased growth of bacteria such as S. aureus and P. aeruginosa (Lipovsky et al., 2010; Lee et al., 2011; Baffoni et al., 2012; Costa and Assis, 2012; Araujo et al., 2013; Kim et al., 2013; Pereira et al., 2014). This suggests that such wavelengths do not interact with chromophores known to exist in these infectious agents. The present study corroborates these findings as our results demonstrate repeatedly that red light with $660 \mathrm{~nm}$ wavelength showed ineffective in inhibiting bacterial growth even at high fluencies between $334.36-603.44 \mathrm{~J} / \mathrm{cm}^{2}$.

Although there are conflicting results reported in the literature (Barboza et al., 2015; Bumah et al., 2015; Rosa et al., 2016), our data can, at least in part explain the reason of such controversies. As we demonstrated several variables must be considered during experimental protocols used such as the distance of the light emitter and the surface, the time of exposure, the cell lineage, the type of medium where the bacteria is growing besides the wavelength itself.

Reports from in vivo experiments show that red light can help fight infections by increasing macrophage migration to the site of infection and stimulating pathogen phagocytosis, representing an indirect antimicrobial mechanism of action (Lu et al., 2016). Based on the in vitro results shown here demonstrating lack of antimicrobial activity from direct exposure to red light, we can suggest that light in the range from 600 to $1100 \mathrm{~nm}$ may not affect certain infectious agent directly. Probably, to be effective it is necessary the presence of immune cells to be activated by this specific type of light and drive a response against the infectious agent.

One factor that is generally ignored in several experimental protocols is the control of the temperature during the irradiation with blue light. The LEDs used in this study can generate heat and promote increase in the temperature on the surface of the agar where bacteria were inoculated, and this is dependent on the distance of the LED and the time of exposure. Thus, the minimum distance of $1 \mathrm{~cm}$ was adopted in this work as a safety measure. It is rare to find description of the temperature measurement in in vitro experiments evaluating the effect of photoemission in bacteria (Bumah et al., 2015; Sousa et al., 2015; Rupel et al., 2019). This may be one of the factors that must be considered since high temperatures may cause heat shock stress in the bacteria or early drying of the culture agar, generating an inhibition unrelated to the effect of light.

In previous pilot studies done to optimize the conditions for the experimental protocol we verified that prolonged exposure of Petri dishes containing S. aureus and Paeruginosa increases the drying of the agar on the dishes and consequently, alters the shape and produces cracks and irregularities on the surface. In these specific areas no bacterial growth could be observed. Such conditions have not been reported in the literature and may be a factor of false positive effect observed in some studies for the red light. The use of infrared filter, as demonstrated 
in this study, has solved this problem and has given more reliability to the results observed here. We also showed that exposure to light after seeding the bacteria inoculum in the Petri dish containing agar is not a real problem to evaluate the effect of light if the precautions are taken. In fact, this is the most common method used in these type of studies (Lipovsky et al., 2010; Dai et al., 2013; Kim et al., 2013; Bumah et al., 2015; Sousa et al., 2015; Masson-Meyers et al., 2015; Halstead et al., 2016; Rosa et al., 2016). We also discarded the hypothesis that the type of material containing agar (glass or polystyrene) where the bacteria are growing may interfere on the effect of the photoemission.

The decrease in the diameters of the bacterial colonies 24 hours after exposure to blue light and return to the normal diameter in the following 48 hours incubation, as shown here, suggests a temporary decrease in the rate of bacterial multiplication induced by the blue light irradiation. Probably, during this growth pause, the bacteria may be expressing genes to eliminate reactive oxygen species responsible for oxidative stress. This may indicate the necessity to expose the bacteria to consecutive treatment with blue light to complete resolution of an infection (Bumah et al., 2013, 2015; Masson-Meyers et al., 2015).

Additionally, it is important to mention that the definition of the light emission parameters itself may represent a problem in studies aiming to identify the antimicrobial activity of light. Therefore, it is important to adopt standard systems of measurement to avoid mistakes in the calculation of irradiance and fluence of the light emitters (Hadis et al., 2016).

To confirm if the inhibition demonstrated for the blue light was independent of the way the light was applied, we irradiated on bacteria inoculated in liquid medium. Herein we tested the irradiation on bacteria inoculated in saline solution and nutrient rich BHI broth. High level of inhibition was observed when blue light was used on both liquid culture media. These results were similar to those reported by Maclean et al. (2009). The mechanism by which blue light can mediate its antimicrobial action is not well established. However, some molecular targets have been suggested as participating in this process. Photosensory systems have been identified in bacteria. Among these systems it is included six receptor protein families namely cryptochrome, blue light-sensing proteins usind FAD (BLUF), light oxygen voltage receptor domain (LOV), photoactive yellow protein (PYP), rhodopsin, and phytochromes (Van der Horst et al., 2007; Gomelsky and Hoff, 2011). Interesting, there are evidence that blue light, but not red light, is able to activate the LOV domain containing protein YtvA by increasing the activity of sigmaB - controlled ctc promoter involved in stress response (Avila-Pérez et al., 2006). Therefore, the presence and functionality of proteins involved in these photosensory systems may be associated to the effectivity of blue light at different degrees depending on the bacteria strain tested and the intensity of light.

Light spectra can interfere differentially in the metabolism of bacteria and substrate usage affecting the respiratory profile. In this context, it has been shown that blue LED has the most decisive impact on substrate utilization by impairing respiration of 140 different substrates tested (Gharaie et al., 2017). This may explain the dufferent results observed here depending on the media used.

Also, it has been proposed that upon interaction of blue light with endogenous porphyrins and flavins it is generated reactive oxygen species (ROS), which in turn could cause oxidative stress, damage the integrity of cell membrane and eventually lead to cell death (Yang et al., 1995), but this has not been demonstrated yet. However, oxidative stress may not be the only cause of cell death (Gharaie et al., 2017). On the other hand, oxygen scavengers may not completely protect bacteria from the toxic effects of blue light. Infrared spectroscopy analysis has demonstrated that DNA cleavage caused by blue light is similar to that observed for UVA treated cells (Bumah et al., 2017). This is expected given spectral proximity of UVA and blue light, which is not the case of red light.

Finally, the results presented here are in agreement with several authors who demonstrated the effect of blue light on the bacterial growth (Maclean et al., 2009; Lipovsky et al., 2010; Dai et al., 2013; Kim et al., 2013; Bumah et al., 2015; Masson-Meyers et al., 2015; Halstead et al., 2016; Rosa et al., 2016; Bumah et al., 2017; Ferrer-Espada et al., 2020; Rupel et al., 2019). The use of higher fluencies (157.78 and $284.90 \mathrm{~J} / \mathrm{cm}^{2}$ ) of blue light caused inhibition in all tests performed for both $S$. aureus and $P$. aeruginosa. It would be important to further investigate the antimicrobial effect of blue light at the molecular level using genomic and proteomic approaches. Thus, we could understand more details on the mechanism of action involved and identify possible novel molecular targets and strategies to fight bacterial infections.

\section{Conclusion}

Blue light at $470 \mathrm{~nm}$ wavelength but not red light at $660 \mathrm{~nm}$ wavelength applied under different conditions is able to decrease the rate of $S$. aureus and P. aeruginosa bacterial growth.

\section{Acknowledgements}

This study was funded in part by the Coordenação de Aperfeiçoamento de Pessoal de Nível Superior Brasil (CAPES) - Fellowship awarded to I. D. C. Galo.

\section{References}

ALVES, P.M., AL-BADI, E., WITHYCOMBE, C., JONES, P.M., PURDY, K.J. and MADDOCKS, S.E., 2018. Interaction between Staphylococcus aureus and Pseudomonas aeruginosa is beneficial for colonisation and pathogenicity in a mixed-biofilm. Pathogens and Disease, vol. 76, no. 1. http://dx.doi.org/10.1093/femspd/fty003. PMid:29342260.

ARAUJO, B.F., SILVA, L.I., MEIRELES, A., ROSA, C.T., GIOPPO, N.M.R., JORGE, A.S., KUNZ, R.I., RIBEIRO, L.F.C., BRANCALHÃO, R.M.C. and BERTOLINI, G.R.F., 2013. Effects of low-level laser therapy, $660 \mathrm{~nm}$, in experimental septic arthritis. ISRN Rheumatology, vol. 2013, pp. 341832. http://dx.doi.org/10.1155/2013/341832. PMid:23997964. 
AVILA-PÉREZ, M., HELLINGWERF, K.J. and KORT, R., 2006. Blue light activates the sigmaB-dependent stress response of Bacillus subtilis via YtvA. Journal of Bacteriology, vol. 188, no. 17, pp. 64116414. http://dx.doi.org/10.1128/JB.00716-06. PMid:16923909.

BAFFONI, M., BESSA, L.J., GRANDE, R., DI GIULIO, M., MONGELLI, M., CIARELLI, A. and CELLINI, L., 2012. Laser irradiation effect on Staphylococcus aureus and Pseudomonas aeruginosa biofilms isolated from venous leg ulcer. International Wound Journal, vol. 9, no. 5, pp. 517-524. http://dx.doi.org/10.1111/j.1742481X.2011.00910.x. PMid:22182280.

BARBOZA, L.L., CAMPOS, V.M.A., MAGALHÃES, L.A.G., PAOLI, F. and FONSECA, A.S., 2015. Low-intensity red and infrared laser effects at high fluences on Escherichia coli cultures. Brazilian Journal of Medical and Biological Research, vol. 48, no. 10, pp. 945-952. http://dx.doi.org/10.1590/1414-431x20154460. PMid:26445339.

BUMAH, V.V., ABOUALIZADEH, E., MASSON-MEYERS, D.S., EELLS, J.T., ENWEMEKA, C.S. and HIRSCHMUGL, C.J., 2017. Spectrally resolved infrared microscopy and chemometric tools to reveal the interaction between blue light $(470 \mathrm{~nm})$ and methicillinresistant Staphylococcus aureus. Journal of Photochemistry and Photobiology. B, Biology, vol. 167, pp. 150-157. http://dx.doi. org/10.1016/j.jphotobiol.2016.12.030. PMid:28064075.

BUMAH, V.V., MASSON-MEYERS, D.S., CASHIN, S. and ENWEMEKA, C.S., 2015. Optimization of the antimicrobial effect of blue light on methicillin-resistant Staphylococcus aureus (MRSA) in vitro. Lasers in Surgery and Medicine, vol. 47, no. 3, pp. 266-272. http:// dx.doi.org/10.1002/lsm.22327. PMid:25639752.

BUMAH, V.V., MASSON-MEYERS, D.S., CASHIN, S.E. and ENWEMEKA, C.S., 2013. Wavelength and bacterial density influence the bactericidal effect of blue light on methicillin-resistant Staphylococcus aureus (MRSA). Photomedicine and Laser Surgery, vol.31, no. 11, pp. 547-553. http://dx.doi.org/10.1089/ pho.2012.3461. PMid:23621894.

CHAMBERS, H.F. and DELEO, F.R., 2009. Waves of resistance: staphylococcus aureus in the antibiotic era. Nature Reviews. Microbiology, vol. 7, no.9, pp.629-641. http://dx.doi.org/10.1038/ nrmicro2200. PMid:19680247.

CHANEY, S.B., GANESH, K., MATHEW-STEINER, S., STROMBERG, P., ROY, S., SEN, C.K. and WOZNIAK, D.J., 2017. Histopathological comparisons of Staphylococcus aureus and Pseudomonas aeruginosa experimental infected porcine burn wounds. Wound Repair and Regeneration, vol. 25, no. 3, pp. 541-549. http:// dx.doi.org/10.1111/wrr.12527. PMid:28466497.

COSTA, A.F. and ASSIS, J.C.L., 2012. In vitro assessment of the bactericidal effect of low-power arsenium-gallium (AsGa) laser treatment. Anais Brasileiros de Dermatologia, vol. 87, no. 4, pp. 654-656. http:// dx.doi.org/10.1590/S0365-05962012000400029. PMid:22892791.

DAI, T., GUPTA, A., HUANG, Y.Y., SHERWOOD, M.E., MURRAY, C.K., VRAHAS, M.S., KIELIAN, T. and HAMBLIN, M.R., 2013. Blue light eliminates community-acquired methicillin-resistant Staphylococcus aureus in infected mouse skin abrasions. Photomedicine and Laser Surgery, vol. 31, no. 11, pp. 531-538. http://dx.doi.org/10.1089/pho.2012.3365. PMid:23406384.

FALKINHAM III, J.O., HILBORN, E.D., ARDUINO, M.J., PRUDEN, A. and EDWARDS, M.A., 2015. Epidemiology and ecology of opportunistic premise plumbing pathogens: Legionella pneumophila, Mycobacterium avium and Pseudomonas aeruginosa. Environmental Health Perspectives, vol. 123, no. 8, pp. 749-758. http://dx.doi.org/10.1289/ehp.1408692. PMid:25793551.

FENG, W., SUN, F., WANG, Q., XIONG, W., QIU, X., DAI, X. and XIA, P., 2017. Epidemiology and resistance characteristics of Pseudomonas aeruginosa isolates from the respiratory department of a hospital in China. Journal of Global Antimicrobial Resistance, vol. 8, pp. 142147. http://dx.doi.org/10.1016/j.jgar.2016.11.012. PMid:28216097.
FERRER-ESPADA, R., WANG, Y., GOH, X.S. and DAI, T., 2020. Antimicrobial blue light inactivation of microbial isolates in biofilms. Lasers in Surgery and Medicine, vol. 52, no. 5, pp. 472-478. http://dx.doi.org/10.1002/lsm.23159. PMid:31536154.

FREITAS, C.H., MENDES, J.F., VILLARREAL, P.V., SANTOS, P.R., GONÇALVES, C.L., GONZALES, H.L. and NASCENTE, P.S., 2018. Identification and antimicrobial suceptibility profile of bacteria causing bovine mastitis from dairy farms in Pelotas, Rio Grande do Sul. Brazilian Journal of Biology = Revista Brasileira de Biologia, vol. 78, no. 4, pp. 661-666. http://dx.doi.org/10.1590/15196984.170727. PMid:29319754.

GALO, I.D.C., LIMA, B.E., SANTOS, T.G., BRAOIOS, A., PRADO, R.P. and SANTOS, W.G., 2020. Staphylococcus aureus growth delay after exposure to low fluencies of blue light $(470 \mathrm{~nm})$. Brazilian Journal of Biology = Revista Brasileira de Biologia . In press. PMid:32490986.

GHARAIE, S., VAAS, L.A.I., ROSBERG, A.K., WINDSTAM, S.T., KARLSSON, M.E., BERGSTRAND, K.J., KHALIL, S., WOHANKA, W. and ALSANIUS, B.W., 2017. Light spectrum modifies the utilization pattern of energy sources in Pseudomonas sp. DR 5-09. PLoS One, vol. 12, no. 12, e0189862. http://dx.doi. org/10.1371/journal.pone.0189862. PMid:29267321.

GOMELSKY, M. and HOFF, W.D., 2011. Light helps bacteria make important lifestyle decisions. Trends in Microbiology, vol. 19, no. 9, pp. 441-448. http://dx.doi.org/10.1016/j.tim.2011.05.002. PMid:21664820.

GOMES, T.F., PEDROSA, M.M., TOLEDO, A.C.L., ARNONI, V.W., MONTEIRO, M.S., PIAI, D.C., SYLVESTRE, S.H.Z. and FERREIRA, B., 2018. Bactericide effect of methylene blue associated with low-level laser therapy in Escherichia coli bacteria isolated from pressure ulcers. Lasers in Medical Science, vol. 33, no. 8, pp. 1723-1731. http://dx.doi.org/10.1007/s10103-018-2528-3. PMid:29744751.

HADIS, M.A., ZAINAL, S.A., HOLDER, M.J., CARROLL, J.D., COOPER, P.R., MILWARD, M.R. and PALIN, W.M., 2016. The dark art of light measurement: accurate radiometry for low-level light therapy. Lasers in Medical Science, vol. 31, no. 4, pp. 789-809. http://dx.doi.org/10.1007/s10103-016-1914-y. PMid:26964800.

HALSTEAD, F.D., THWAITE, J.E., BURT, R., LAWS, T.R., RAGUSE, M., MOELLER, R., WEBBER, M.A. and OPPENHEIM, B.A., 2016. Antibacterial activity of blue light against nosocomial wound pathogens growing planktonically and as mature biofilms. Applied and Environmental Microbiology, vol. 82, no. 13, pp. 40064016. http://dx.doi.org/10.1128/AEM.00756-16. PMid:27129967.

KHAN, H.A., BAIG, F.K. and MEHBOOB, R., 2017. Nosocomial infections: epidemiology, prevention, control and surveillance. Asian Pacific Journal of Tropical Biomedicine, vol. 7, no. 5, pp. 478-482. http://dx.doi.org/10.1016/j.apjtb.2017.01.019.

KIM, S., KIM, J., LIM, W., JEON, S., KIM, O., KOH, J.T., KIM, C.S., CHOI, H. and KIM, O., 2013. In vitro bactericidal effects of 625, 525 and $425 \mathrm{~nm}$ wavelength (red, green and blue) light-emitting diode irradiation. Photomedicine and Laser Surgery, vol. 31, no. 11, pp. 554562. http://dx.doi.org/10.1089/pho.2012.3343. PMid:24138193.

LEE, S.Y.C., SEONG, I.W., KIM, J.S., CHEON, K.A., GU, S.H., KIM, H.H. and PARK, K.H., 2011. Enhancement of cutaneous immune response to bacterial infection after low-level light therapy with $1072 \mathrm{~nm}$ infrared light: a preliminary study. Journal of Photochemistry and Photobiology. B, Biology, vol. 105, no. 3, pp. 175-182. http:// dx.doi.org/10.1016/j.jphotobiol.2008.06.008. PMid:21955546.

LIPOVSKY, A., NITZAN, Y., GEDANKEN, A. and LUBART, R., 2010. Visible light-induced killing of bacteria as a function of wavelength: implication for wound healing. Lasers in Medical Science, vol. 42, no. 6, pp. 467-472. http://dx.doi.org/10.1002/ Ism.20948. PMid:20662022. 
LU, C., FAN, Z. and XING, D., 2016. Photo-enhancement of macrophage phagocytic activity via Rac1-mediated signaling pathway: implications for bacterial infection. The International Journal of Biochemistry \& Cell Biology, vol. 78, pp. 206-216. http://dx.doi. org/10.1016/j.biocel.2016.06.010. PMid:27345261.

LUCCA, A.J., CARTER-WIENTJES, C., WILLIAMS, K.A. and BHATNAGAR, D., 2012. Blue light ( $470 \mathrm{~nm}$ ) effectively inhibits bacterial and fungal growth. Letters in Applied Microbiology, vol. 55, no. 6, pp. 460-466. http://dx.doi.org/10.1111/lam.12002. PMid:23009190.

LUPKE, K.H., SUDA, K.J., BOUCHER, H., RUSSO, R.L., BONNEY, M.W., HUNT, T.D. and MOHR, J.F., 2017. Past, present and future of antibacterial economics: increasing bacterial resistance, limited antibiotic pipeline and societal implications. Pharmacotherapy, vol. 37, no. 1, pp. 71-84. http://dx.doi.org/10.1002/phar.1868. PMid:27859453.

MACLEAN, M., MACGREGOR, S.J., ANDERSON, J.G. and WOOLSEY, G., 2009. Inactivation of bacterial pathogens following exposure to light from a 405-nanometer light-emiting diode array. Applied and Environmental Microbiology, vol. 75, no. 7, pp. 1932-1937. http://dx.doi.org/10.1128/AEM.01892-08. PMid:19201962.

MARCIANO, R.S., SERGIO, L.P.S., POLIGNANO, G.A.C., PRESTA, G.A., GUIMARÃES, O.R., GELLER, M., PAOLI, S., PAOLI, F. and FONSECA, A.S., 2012. Laser for treatment of aphthous ulcers on bacteria cultures and DNA. Photochemical \& Photobiological Sciences, vol. 11, no. 9, pp. 1476-1483. http://dx.doi.org/10.1039/c2pp25027f. PMid:22766761.

MASSON-MEYERS, D.S., BUMAH, V.V., BIENER, G., RAICU, V. and ENWEMEKA, C.S., 2015. The relative antimicrobial effect of blue $405 \mathrm{~nm}$ LED and blue $405 \mathrm{~nm}$ laser on methicillin-resistant Staphylococcus aureus in vitro. Lasers in Medical Science, vol. 30, no. 9, pp. 2265-2271. http://dx.doi.org/10.1007/s10103015-1799-1. PMid:26362142.

MONACO, M., ARAUJO, F.P., CRUCIANI, M., COCCIA, E.M. and PANTOSTI, A., 2017. Worldwide epidemiology and antibiotic resistance of Staphylococcus aureus. Current Topics in Microbiology and Immunology, vol. 409, pp. 21-56. http://dx.doi. org/10.1007/82_2016_3. PMid:27025380.

OLIVER, A., MULET, X., LÓPEZ-CAUSAPÉ, C. and JUAN, C., 2015. The increasing threat of Pseudomonas aeruginosa high-risk clones. Drug Resistance Updates, vol. 21-22, pp. 41-59. http://dx.doi. org/10.1016/j.drup.2015.08.002. PMid:26304792.

ÖZBERK, S.S., GÜNDOGAR, H., S̨ENYURT, S.Z. and ERCIYAS, K., 2018. Adjunct use of low-level laser therapy on the treatment of necrotizing ulcerative gengivitis: a case report. Journal of Lasers in Medical Sciences, vol. 9, no. 1, pp. 73-75. http://dx.doi. org/10.15171/jlms.2018.15. PMid:29399316.
PEREIRA, P.R., PAULA, J.B., CIELINSKI, J., PILONETTO, M. and VON BAHTEN, L.C., 2014. Effects of low intensity laser in in vitro bacterial culture and in vivo infected wounds. Revista do Colégio Brasileiro de Cirurgiões, vol. 41, no. 1, pp. 49-55. http://dx.doi. org/10.1590/S0100-69912014000100010. PMid:24770774.

ROSA, L.P., SILVA, F.C., VIANA, M.S. and MEIRA, G.A., 2016. In vitro effectiveness of 455-nm blue LED to reduce the load of Staphylococcus aureus and Candida albicans biofilms in compact bone tissue. Lasers in Medical Science, vol. 31, no. 1, pp. 27-32. http://dx.doi.org/10.1007/s10103-015-1826-2. PMid:26498601.

RUPEL, K., ZUPIN, L., OTTAVIANI, G., BERTANI, I., MARTINELLI, V., PORRELLI, D., VODRET, S., VUERICH, R., SILVA, D.P., BUSSANI, R., CROVELLA, S., PARSEK, M., VENTURI, V., DI LENARDA, R., BIASOTTO, M. and ZACCHIGNA, S., 2019. Blue laser light inhibits biofilm formation in vitro and in vivo by inducing oxidative stress. NPJ Biofilms and Microbiomes, vol. 5, no. 29, pp. 29. http://dx.doi.org/10.1038/s41522-019-0102-9. PMid:31602310.

SCHWARZ, S., LOEFFLER, A. and KADLEC, K., 2017. Bacterial resistance to antimicrobial agents and its impact on veterinary and human medicine. Veterinary Dermatology, vol. 28, no. 1, pp. 82-e19. http://dx.doi.org/10.1111/vde.12362. PMid:27581211.

SOUSA, N.T., SANTOS, M.F. and GOMES, R.C., 2015. Blue laser inhibits bacterial growth of Staphylococcus aureus, Escherichia coli and Pseudomonas aeruginosa. Photomedicine and Laser Surgery, vol. 33, no. 5, pp. 278-282. http://dx.doi.org/10.1089/pho.2014.3854. PMid:25954830.

VAN DER HORST, M.A., KEY, J. and HELLINGWERF, K.J., 2007. Photosensing in chemotrophic, non-phototrophic bacteria: let the be light sensing too. Trends in Microbiology, vol. 18, no. 12, pp. 554-562. http://dx.doi.org/10.1016/j.tim.2007.09.009. PMid: 18024131.

WORLD HEALTH ORGANIZATION - WHO, 2014 [viewed 3 December 2019]. Antimicrobial resistance: global report on surveillance [online]. Geneva: WHO. Available from: http://www.who.int/ drugresistance/documents/surveillancereport/en/

WORLD HEALTH ORGANIZATION - WHO, 2017 [viewed 3 December 2019]. WHO publishes list of bacteria for which new antibiotics are urgently needed [online]. Geneva: WHO. Available from: http://www.who.int/mediacentre/news/releases/2017/bacteriaantibiotics-needed/en/

YANG, H., INOKUCHI, H. and ADLER, J., 1995. Phototaxis away from blue light by an Escherichia coli mutant accumulating protoporphyrin IX. Proceedings of the National Academy of Sciences of the United States of America, vol. 92, no. 16, pp. 7332-7336. http://dx.doi.org/10.1073/pnas.92.16.7332. PMid:7638191. 